\title{
Karakter Kualitatif Dan Kuantitatif Beberapa Varietas Padi (Oryza sativa L.) Terhadap Cekaman Salinitas (NaCl)
}

\author{
Author(s): Mohammad Irvan Muttaqien ${ }^{(1)}$, Dwi Rahmawati( ${ }^{(1)}$ \\ (1) Politeknik Negeri Jember \\ * Corresponding author:mohammadmuttaqien17@gmail.com
}

\begin{abstract}
ABSTRAK
Salah satu upaya untuk meningkatkan produktivitas padi di lahan pasang surut yang mengandung cekaman salinitas $(\mathrm{NaCl})$ dengan menggunakan karakter varietas yang toleran. Penelitian ini dilaksanakan selama 6 bulan, dari bulan Agustus sampai Desember 2017 di desa Kreongan, kecamatan Patrang, Kabupaten Jember. Penelitian ini menggunakan rancangan acak kelompok non factorial (RAK) dengan 1 faktor dan 4 ulangan. Perlakuan varietas yang digunakan adalah Inpari 42 (V1), IPB 3S (V2), IR64 (V3), Ciherang (V4), Mekongga (V5), IR66 (V6), Sintanur (V7). Hasil penelitian pada tanah yang mengandung cekaman salinitas $(\mathrm{NaCl}) 5303,45$ ppm menunjukkan bahwa karakter kualitatif semua varietas sesuai dengan deskripsi varietas sedangkan karakter kuantitatif menunjukkan bahwa perlakuan varietas berpengaruh nyata pada tinggi tanaman vegetatif, dan berpengaruh sangat nyata pada tingkat toleransi tanaman, tinggi tanaman generatif, panjang daun bendera, panjang malai, jumlah gabah per malai, jumlah gabah bernas, bobot 1000 butir, jumlah anakan, jumlah anakan produktif, produksi per hektar, potensi hasil per hektar, daya berkecambah, kecepatan tumbuh serta keserempakan tumbuh benih. Hasil menunjukkan bahwa Varietas Sintanur menunjukkan hasil terbaik pada produksi per hektar, potensi hasil dan kualitas benih. Inpari 42, IPB 3S, IR64, Ciherang, mekongga, Sintanur adalah varietas toleran dan IR66 cukup toleran.
\end{abstract}

\section{Kata Kunci:}

Cekaman Salinitas $(\mathrm{NaCl})$;

Karakter

kualitatif;

Karakter

kuantitatif;

Varietas Padi;

\begin{abstract}
Keywords:
Character

One way to increase rice productivity in tidal lands containing salinity stress ( $\mathrm{NaCl})$ using characters tolerant varieties. This research was conducted for 6 months, from July qualitative; to December 2017 in Kreongan Village, Patrang Subdistrict, Jember Regency. This

Character quantitave;

Rice Variety;

Salinity Stress $(\mathrm{NaCl})$; research uses Non Factorial Random Block Design (RBD) with 1 factor and 4 replications. Varieties treatment used were Inpari 42 (V1), IPB 3S (V2), IR64 (V3), Ciherang (V4), Mekongga (V5), IR66 (V6), and Sintanur (V7). The result of the research on soil containing 5303,45 ppm of salinity stress showed that qualitative character of all varieties match with the description, while quantitative character showed that the rice variety has significant effect on the vegetative plant height. The rice variety factor was also shown a real significant effect on the plants level tolerance, generative plant height, leaf flag length, length of panicle, number of grain each panicle, number of pithy grain, weight of 1000 grains, number of tiller, number of tiller productive, production per hectare, yield potential, germination capacity, germination speed and seed germination sequential. The results showed that the Sintanur variety showed the best result in production each hectare, yield potential and seed quality. Inpari 42, IPB 3S, IR64, Ciherang, Mekongga, Sintanur are tolerant varieties and IR66 is moderately tolerant.
\end{abstract}

ABSTRACT 


\section{PENDAHULUAN}

Pertumbuhan penduduk di Indonesia yang terus meningkat, sehingga kebutuhan beras sebagai makanan pokok semakin tinggi (Hutajulu, Rosmayati, \& Ilyas, 2013). Adanya pergantian fungsi lahan menyebabkan produksi padi menjadi berkurang. Menurut Badan Pusat Statistik (2017), pada tahun 2014, luas panen untuk komoditas padi di Indonesia mengalami penurunan sebesar 319.331 hektar yang mengakibatkan penurunan produksi sebesar 4.551.376 ton disamping diakibatkan oleh produktivitas yang rendah.

Salah satu cara meningkatkan produksi padi adalah dengan perluasan areal tanam. Perluasan areal tanam dapat dilakukan dengan memanfaatkan lahanlahan marjinal yaitu lahan rawa jenis pasang surut. Luas lahan rawa jenis pasang surut pada beberapa pulau besar di Indonesia seluas 8.535.708 hektar (Alwi, 2014). Rawa jenis pasang surut termasuk pada lahan salin. Menurut Utama et al. (2009) bahwa lahan yang terkontaminasi garam dapat menghambat pertumbuhan dan perkembangan tanaman.

Untuk dapat memanfaatkan lahanlahan marjinal tersebut dibutuhkan teknologi dan varietas toleran terhadap cekaman garam. Suatu varietas digolongkan sebagai varietas toleran apabila tumbuh baik walaupun mengalami sedikit hambatan pertumbuhan dan produksi $(<25 \%)$ saat mengalami cekaman (Utama et al., 2009).

Varietas padi yang toleran salinitas yang dianjurkan untuk budidaya di lahan sawah rawa terintrusi air laut adalah varietas IR64 (Utama et al., 2009). Hutajulu et al. (2013) menambahkan bahwa varietas Ciherang juga toleran cekaman salinitas. Varietas Sintanur merupakan varietas dengan vigor fase vegetatif tanaman utama yang lebih baik dan berpotensi ratun tinggi di lahan pasang surut (Kesmayanti \& Mareza, 2015).
Pemuliaan tanaman dilakukan dengan mengkarakter dan menyeleksi tanaman secara kualitatif dan kuantitatif sehingga mendapatkan plasma-plasma yang dapat dikembangkan untuk memperbaiki generasi-generasi tanaman menjadi lebih baik di lahan tercekam salinitas $(\mathrm{NaCl})$. Oleh karena itu, penelitian ini bertujuan untuk mengetahui karakter kualitatif dan kuantitatif beberapa varietas padi yang toleran terhadap cekaman salinitas $(\mathrm{NaCl})$

\section{BAHAN DAN METODE}

Penelitian ini dilaksanakan pada bulan Juli sampai dengan bulan Desember 2017, bertempat di lahan Desa Kreongan, Kecamatan Patrang, Kabupaten Jember dengan suhu rata-rata $25,6^{\circ} \mathrm{C}$, curah hujan $2447 \mathrm{~mm} /$ tahun (Badan Meteorologi, 2017) dan Laboratorium Teknologi Benih, Politeknik Negeri Jember.

Bahan yang digunakan antara lain; Benih padi 7 varietas (Inpari 42, IPB 3S, IR64, Ciherang, Mekongga, IR66, Sintanur), Pupuk (Urea, SP36, KCl), Tanah salinitas, Kertas label, Tali raffia, Pestisida kimia (Furadan 3GR, Prevathon 50 SC, Regent 50g/l, Dithane M-45 80WP).

Rancangan percobaan dalam penelitian ini menggunakan Rancangan Acak Kelompok (RAK) Non Faktorial dengan 1 faktor yaitu Varietas (V), yang terdiri dari 7 taraf : V1 = Inpari 42, V2 = IPB 3S, V3 = IR64, V4 = Ciherang, V5 = Mekongga, V6 = IR66 dan V7 = Sintanur. Kombinasi perlakuan diulang 4 kali sehingga terdapat 28 unit percobaan. Analisis data menggunakan uji $\mathrm{F}$ apabila berbeda nyata dilanjutkan Uji BNJ (Beda Nyata Jujur) taraf error 5\%.

Penelitian ini dilakukan dengan merendam dan memeram benih dengan air bersih selama 24 jam, selanjutnya menanam benih padi 7 varietas menggunakan sistem tanam benih langsung (TABELA) pada media tanah yang mengandung kadar $\mathrm{NaCl}$ 5303,45 
ppm dan $\mathrm{pH}$ 7.9. Pelaksanaan selanjutnya meliputi pemeliharaan, panen dan pasca panen.

Parameter pengamatan dilakukan pada seluruh unit perlakuan dengan jumlah sampel 3 tanaman per unit perlakuan. Parameter pengamatan dalam penelitian ini meliputi karakter kualitatif (bentuk tanaman, warna batang, permukaan daun, warna kaki, warna lidah daun, warna telinga daun, warna gabah, bentuk gabah) dan karakter kuantitatif (tingkat toleransi tanaman, tinggi tanaman vegetatif, jumlah anakan, lama stadia vegetatif, umur berbunga, lama stadia generatif, umur panen, tinggi tanaman generatif, panjang malai, panjang daun bendera, jumlah anakan produktif, jumlah gabah per malai, jumlah gabah bernas per malai, persentase gabah hampa per malai, produksi per hektar, bobot 1000 butir benih) serta uji mutu benih (daya berkecambah, kecepatan tumbuh, keserempakan tumbuh benih).

\section{HASIL DAN PEMBAHASAN} Karakter Kualitatif

Karakter kualitatif merupakan karakter yang dibedakan berdasarkan kelas atau jenisnya, baik dilakukan secara visual maupun menggunakan skor.

Tabel 1. Rangkuman Hasil Pengamatan Karakter Kualitatif

\begin{tabular}{|c|c|c|c|c|c|c|c|}
\hline \multirow{2}{*}{ Karakter } & \multicolumn{7}{|c|}{ Varietas } \\
\hline & V1 & $\mathrm{V} 2$ & V3 & V4 & V5 & V6 & V7 \\
\hline $\begin{array}{c}\text { Bentuk } \\
\text { tanaman }\end{array}$ & Tegak & Tegak & Tegak & Tegak & Tegak & Tegak & Tegak \\
\hline Warna batang & Hijau & Hijau & Hijau & Hijau & Hijau & Hijau tua & Hijau \\
\hline Warna kaki & Hijau & Hijau & Hijau & Hijau & Hijau & Hijau tua & Hijau \\
\hline $\begin{array}{l}\text { Permukaan } \\
\text { daun }\end{array}$ & Kasar & Berbulu & Kasar & $\begin{array}{c}\text { Kasar di bagian } \\
\text { bawah }\end{array}$ & Agak kasar & Kasar & Kasar \\
\hline $\begin{array}{c}\text { Warna lidah } \\
\text { daun }\end{array}$ & $\begin{array}{c}\text { Tidak } \\
\text { berwarna }\end{array}$ & $\begin{array}{c}\text { Tidak } \\
\text { berwarna }\end{array}$ & $\begin{array}{c}\text { Tidak } \\
\text { berwarna }\end{array}$ & Tidak berwarna & $\begin{array}{c}\text { Tidak } \\
\text { berwarna }\end{array}$ & $\begin{array}{c}\text { Tidak } \\
\text { berwarna }\end{array}$ & $\begin{array}{c}\text { Tidak } \\
\text { berwarna }\end{array}$ \\
\hline $\begin{array}{c}\text { Warna } \\
\text { telinga daun }\end{array}$ & $\begin{array}{c}\text { Tidak } \\
\text { berwarna }\end{array}$ & $\begin{array}{c}\text { Tidak } \\
\text { berwarna }\end{array}$ & $\begin{array}{c}\text { Tidak } \\
\text { berwarna }\end{array}$ & Tidak berwarna & $\begin{array}{c}\text { Tidak } \\
\text { berwarna }\end{array}$ & $\begin{array}{c}\text { Tidak } \\
\text { berwarna }\end{array}$ & $\begin{array}{c}\text { Tidak } \\
\text { berwarna }\end{array}$ \\
\hline Warna daun & Hijau & Hijau & Hijau & Hijau & Hijau & Hijau & Hijau \\
\hline Warna gabah & $\begin{array}{l}\text { Kuning } \\
\text { jerami }\end{array}$ & $\begin{array}{l}\text { Kuning } \\
\text { jerami }\end{array}$ & $\begin{array}{c}\text { Kuning } \\
\text { bersih }\end{array}$ & Kuning bersih & $\begin{array}{c}\text { Kuning } \\
\text { bersih }\end{array}$ & $\begin{array}{c}\text { Kuning } \\
\text { bersih }\end{array}$ & $\begin{array}{c}\text { Kuning } \\
\text { bersih }\end{array}$ \\
\hline Bentuk gabah & Ramping & Ramping & Ramping & Ramping & Ramping & Ramping & Sedang \\
\hline
\end{tabular}

Keterangan : Inpari 42 (V1), IPB 3S (V2), IR64 (V3), Ciherang (V4), Mekongga (V5), IR66 (V6), Sintanur (V7)

Berdasarkan Tabel 1. menunjukkan semua karakter kualitatif sesuai dengan deskripsi varietasnya. Hal ini diduga karakter kualitatif dikendalikan oleh sedikit gen dan sedikit dipengaruhi lingkungan meskipun pada tanah salin. Syukur et al., (2015) menambahkan karakter kualitatif sedikit dipengaruhi faktor lingkungan dan karakter ini dikendalikan oleh gen sederhana. Karakter kualitatif menunjukkan penampilan yang seragam (Nusifera, Lestari, \& Alia, 2014).

\section{Karakter Kuantitatif Tingkat Toleransi Tanaman}

Menurut Gregorio et al., (1997), pengujian salinitas pada padi dilakukan pada stadia bibit dan pada 10-16 hari setelah pemberian garam. Pada hasil pengamatan menunjukkan bahwa tingkat toleransi tanaman berbeda sangat nyata. Sehingga dilakukan uji lanjut BNJ dengan taraf error $5 \%$. 


\begin{tabular}{lcl}
$\begin{array}{l}\text { Tabel 2. Rerata } \\
\text { Tanaman }\end{array}$ & Tingkat & \multicolumn{1}{c}{ Toleransi } \\
\hline Varietas & $\begin{array}{l}\text { Persentase } \\
\text { Daun Mati } \\
(\%)\end{array}$ & $\begin{array}{l}\text { Tingkat } \\
\text { Toleransi }\end{array}$ \\
\hline Inpari 42 (V1) & $13 \mathrm{a}$ & Toleran \\
IPB 3S (V2) & $31 \mathrm{abc}$ & Toleran \\
IR64 (V3) & $23 \mathrm{ab}$ & Toleran \\
Ciherang (V4) & $26 \mathrm{ab}$ & Toleran \\
Mekongga (V5) & $38 \mathrm{bc}$ & Toleran \\
IR66 (V6) & $51 \mathrm{c}$ & Agak Toleran \\
Sintanur (V7) & $17 \mathrm{ab}$ & Toleran \\
\hline
\end{tabular}

Keterangan:

Angka yang diikuti oleh huruf yang sama menunjukkan berbeda tidak nyata menurut uji lanjut BNJ 5\%

Berdasarkan Tabel 2. tampak bahwa perlakuan Varietas Inpari 42 (V1) menunjukkan persentase daun mati yang rendah yaitu 13\% (toleran). Hal tersebut diduga karena Inpari 42 (V1) merupakan varietas toleran cekaman salinitas (Balai Besar Penelitian Tanaman Padi, 2016).

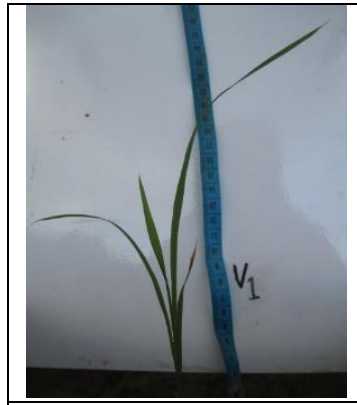

a) Varietas Inpari 42 (V1)

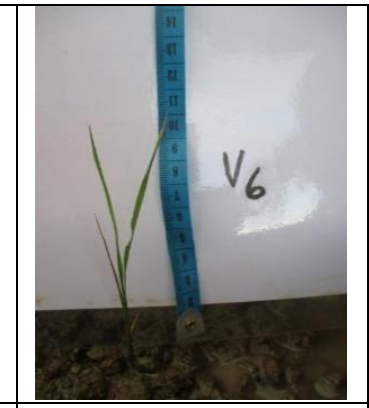

b) Varietas IR66 (V6)
Keterangan : a) Toleran salinitas $(\mathrm{NaCl})$

b) Agak toleran salinitas $(\mathrm{NaCl})$

Gambar 1. Varietas Padi pada Cekaman Salinitas

Terjadi perubahan yang khas pada anatomi dan morfologi untuk memperbaiki status air tanaman, seperti ukuran daun lebih kecil, jumlah stomata lebih sedikit, penebalan kutikula, berkurangnya diferensiasi,perkembangan jaringan pembuluh, dan lignifikasi akar lebih awal, merupakan mekanisme morfologi terhadap ketahanan salinitas (Mindari, 2009).

\section{Fase Vegetatif}

Makarim and Suhartatik (2009) menyatakan bahwa fase vegetatif adalah fase pertumbuhan dari organ-organ vegetatif, seperti: pertambahan jumlah anakan, tinggi tanaman, jumlah bobot dan luas daun.Tinggi tanaman fase vegetatif dilakukan pada fase bibit yaitu 21 hari setelah tanam benih langsung. Hayuningtyas (2010) menambahkan bahwa kepekaan tanaman pada tahap pertama adalah tahap perkecambahan dan fase kedua adalah pada saat awal bibit padi dan kepekaan ini berakhir pada saat tahap pembungaan dan penyerbukan. Pada hasil pengamatan menunjukkan bahwa tinggi tanaman vegetatif dan jumlah anakan berbeda sangat nyata. Sehingga dilakukan uji lanjut BNJ dengan taraf error 5\%. Sedangkan lama stadia vegetatif tidak memberikan pengaruh nyata.

Tabel 3. Rerata Tinggi Tanaman Vegetatif (cm), Jumlah Anakan dan Lama Stadia Vegetatif (hari)

\begin{tabular}{|c|c|c|c|}
\hline Varietas & $\begin{array}{l}\text { Tinggi } \\
\text { Tanaman } \\
\text { Vegetatif } \\
(\mathrm{cm})\end{array}$ & $\begin{array}{l}\text { Jumlah } \\
\text { Anakan }\end{array}$ & $\begin{array}{l}\text { Lama } \\
\text { Stadia } \\
\text { Vegetatif } \\
\text { (hari) (ns) }\end{array}$ \\
\hline $\begin{array}{l}\text { Inpari } 42 \\
\text { (V1) }\end{array}$ & $26,17 \mathrm{~b}$ & $25,33 \mathrm{~b}$ & 79,75 \\
\hline $\begin{array}{l}\text { IPB 3S } \\
\text { (V2) }\end{array}$ & $25,67 \mathrm{~b}$ & $14,25 \mathrm{a}$ & 82,67 \\
\hline IR64 (V3) & $24,67 \mathrm{ab}$ & $29,21 \mathrm{bc}$ & 75,42 \\
\hline $\begin{array}{l}\text { Ciherang } \\
\text { (V4) }\end{array}$ & $23,75 \mathrm{ab}$ & $28,42 \mathrm{~b}$ & 81,08 \\
\hline $\begin{array}{l}\text { Mekongga } \\
\text { (V5) }\end{array}$ & $20,08 \mathrm{ab}$ & $27,00 \mathrm{~b}$ & 82,67 \\
\hline IR66 (V6) & $18,75 \mathrm{a}$ & $27,25 \mathrm{~b}$ & 76,79 \\
\hline $\begin{array}{l}\text { Sintanur } \\
\text { (V7) }\end{array}$ & $23,25 \mathrm{ab}$ & $35,25 \mathrm{c}$ & 77,92 \\
\hline
\end{tabular}

Keterangan:

- ns = berbeda tidak nyata

- Angka yang diikuti oleh huruf yang sama menunjukkan berbeda tidak nyata menurut uji lanjut BNJ 5\% 
Dari ketujuh varietas yang diuji, menunjukkan bahwa tinggi tanaman fase vegetatif yang tertinggi yaitu $26,17 \mathrm{~cm}$ pada Varietas Inpari 42 (V1) dan tinggi tanaman terendah ditemukan pada Varietas IR66 (V6) yaitu 18,75 cm. Sebaliknya untuk jumlah anakan tampak bahwa Varietas Sintanur (V7) memiliki jumlah anakan paling banyak yaitu 35,25 anakan dan Varietas IPB 3S (V2) memiliki jumlah anakan paling sedikit yaitu 14,25 anakan. Sedangkan lama stadia vegetatif secara umum semua varietas tidak memiliki perbedaan yang nyata.

Adanya perbedaan yang nyata pada tinggi tanaman fase vegetatif dan jumlah anakan menunjukkan adanya mekanisme berbeda dari setiap varietas dalam mengatasi cekaman salinitas $(\mathrm{NaCl})$. Tanah yang digunakan sebagai media tumbuh padi dalam penelitian ini mengandung kadar $\mathrm{NaCl}$ tinggi yaitu 5303,45 ppm. Sedangkan menurut Gregorio et al., (1997) bahwa tanaman padi mengalami keracunan salinitas ketika kadar $\mathrm{NaCl} 4000$ ppm. Rusd (2011) menyatakan bahwa semakin tinggi tingkat konsentrasi garam pertumbuhan tanaman semakin terhambat. Jumlah anakan diduga dikendalikan oleh faktor genetik. Hal ini diperkuat oleh Makarim and Suhartatik, (2009) bahwa secara genetik varietas tanaman menentukan jumlah anakan.

Lama fase vegetatif padi dimulai dari benih berkecambah sampai dengan bunting. Lamanya stadia vegetatif diduga karena pengaruh genetik. Menurut Makarim and Suhartatik (2009), perbedaan umur tanaman ditentukan oleh lamanya fase vegetatif. Lama fase ini menjadi sasaran pemuliaan untuk memperpendek umur tanaman.

\section{Fase Generatif}

Fase generatif dimulai dari fase reproduktif sampai fase pematangan.
Tabel 4. Rerata Umur Berbunga (hari) dan Lama Stadia Generatif (hari)

\begin{tabular}{lll}
\hline Varietas & $\begin{array}{l}\text { Umur } \\
\text { Berbunga } \\
\text { (hari) }\end{array}$ & $\begin{array}{l}\text { Lama Stadia } \\
\text { Generatif } \\
\text { (hari) }\end{array}$ \\
\hline Inpari 42 (V1) & 82,75 & 47,67 \\
IPB 3S (V2) & 85,67 & 46,83 \\
IR64 (V3) & 78,42 & 50,50 \\
Ciherang (V4) & 84,08 & 46,75 \\
Mekongga (V5) & 85,67 & 45,58 \\
IR66 (V6) & 79,79 & 50,83 \\
Sintanur (V7) & 80,92 & 49,08 \\
\hline
\end{tabular}

Berdasarkan Tabel 4. tampak bahwa pada umur berbunga dan lama stadia generatif menunjukkan berbeda tidak nyata (ns) pada semua varietas yang diuji. Menurut Makarim and Suhartatik (2009) bahwa varietas padi secara umum yang hidup di daerah tropik mengalami lama fase reproduktif 35 hari dan fase pematangan kurang lebih 30 hari. Hal ini berarti bahwa lama stadia generatif semua varietas yang diuji mengalami kemunduran antara 15 sampai 20 hari.

Tabel 5. Rerata Umur Panen (hari)

\begin{tabular}{lll}
\hline \multirow{2}{*}{ Varietas } & \multicolumn{2}{c}{ Umur Panen (hari) } \\
\cline { 2 - 3 } & $\begin{array}{l}\text { Kondisi } \\
\text { Cekaman } \\
\text { Salinitas } \\
\text { (NaCl) }\end{array}$ & $\begin{array}{l}\text { Deskripsi } \\
\text { Varietas }\end{array}$ \\
\hline Inpari 42 (V1) & 130,42 & \pm 112 \\
IPB 3S (V2) & 132,50 & 112 \\
IR64 (V3) & 130,00 & $110-120$ \\
Ciherang (V4) & 130,83 & $116-125$ \\
Mekongga (V5) & 131,25 & $116-125$ \\
IR66 (V6) & 130,63 & $110-120$ \\
Sintanur (V7) & 130,00 & $115-125$ \\
\hline
\end{tabular}

Tabel 5. tampak bahwa pada umur panen menunjukkan berbeda tidak nyata (ns) pada semua varietas yang diuji. Umur panen pada kondisi cekaman salinitas $(\mathrm{NaCl})$ mengalami keterlambatan antara 518 hari apabila dibandingkan dengan deskripsi masing masing varietas. 
Hal ini diduga karena lingkungan tempat tumbuh memberikan pengaruh yang cukup besar. Salinitas adalah faktor lingkungan yang berpengaruh pada pertumbuhan dan produktivitas tanaman. Hambatan pertumbuhan yang dialami padi cekaman salinitas dapat berupa berubahnya warna daun, tinggi tanaman yang tidak optimal, umur berbunga yang terlambat sampai tanaman yang tidak menghasilkan biji (Kurniasih, Tarnoyo, \& Toekidjo, 2008).

Tabel 6. Rerata Tinggi Tanaman Generatif (cm)

\begin{tabular}{lll}
\hline & $\begin{array}{l}\text { Tinggi Tanaman Generatif } \\
(\mathrm{cm})\end{array}$ \\
\cline { 2 - 3 } Varietas & $\begin{array}{l}\text { Kondisi } \\
\text { Cekaman } \\
\end{array}$ & $\begin{array}{l}\text { Deskripsi } \\
\text { Valinitas } \\
(\mathrm{NaCl})\end{array}$ \\
& $84,83 \mathrm{ab}$ & \pm 93 \\
\hline Inpari 42 (V1) & $101,17 \mathrm{c}$ & 118 \\
IPB 3S (V2) & $84,20 \mathrm{ab}$ & $115-126$ \\
IR64 (V3) & $83,08 \mathrm{ab}$ & $107-115$ \\
Ciherang (V4) & $91-106$ \\
Mekongga (V5) & $79,42 \mathrm{a}$ & $90-99$ \\
IR66 (V6) & $75,71 \mathrm{a}$ & $115-125$ \\
Sintanur (V7) & $95,92 \mathrm{bc}$ & \\
\hline Keterangan: & & yang sama \\
Angka yang diikuti oleh huruf \\
menunjukkan berbeda tidak nyata & menurut uji \\
lanjut BNJ 5\% & &
\end{tabular}

Hasil uji lanjut Tabel 6. tampak bahwa karakter tinggi tanaman dari ketujuh varietas padi rata-rata mengalami penurunan antara 8 sampai $31 \mathrm{~cm}$ dibandingkan dengan deskripsi varietas. Perubahan karakter yang muncul diduga karena kemampuan tanaman dalam beradaptasi yang dipengaruhi oleh genetik dan lingkungan. Tanaman yang mengalami cekaman salinitas $(\mathrm{NaCl})$ beradaptasi dengan menunjukkan tinggi tanaman yang terhambat. Menurut Mindari (2009), respon tanaman yang mengalami stress garam pada umumnya tidak merusak secara langsung tetapi dalam bentuk pertumbuhan tanaman yang terhambat dan berubah secara perlahan.
Tabel 7. Rerata Jumlah Anakan Produktif

\begin{tabular}{lll}
\hline & \multicolumn{2}{l}{ Jumlah Anakan Produktif } \\
\cline { 2 - 3 } Varietas & $\begin{array}{l}\text { Kondisi } \\
\text { Cekaman } \\
\text { Salinitas } \\
\text { (NaCl) }\end{array}$ & $\begin{array}{l}\text { Deskripsi } \\
\text { Varietas }\end{array}$ \\
& $19,92 \mathrm{~cd}$ & - \\
\hline Inpari 42 (V1) & $7,58 \mathrm{a}$ & $7-11$ \\
IPB 3S (V2) & $21,42 \mathrm{de}$ & $20-35$ \\
IR64 (V3) & $20,67 \mathrm{de}$ & $14-17$ \\
Ciherang (V4) & $17,00 \mathrm{c}$ & $13-16$ \\
Mekongga (V5) & $13,25 \mathrm{~b}$ & $14-17$ \\
IR66 (V6) & $23,75 \mathrm{e}$ & $16-20$ \\
Sintanur (V7) & & \\
\hline
\end{tabular}

Keterangan:

Angka yang diikuti oleh huruf yang sama menunjukkan berbeda tidak nyata menurut uji lanjut BNJ 5\%

Hasil uji lanjut pada Tabel 7. tampak bahwa jumlah anakan produktif Varietas IPB 3S (V2) terendah yaitu 7,58 anakan, sedangkan tertinggi pada Varietas Sintanur (V7) yaitu 23,75 anakan. Varietas Sintanur (V7) pada kondisi cekaman salinitas $(\mathrm{NaCl})$ dapat menghasilkan 4 anakan produktif lebih banyak dibandingkan dengan deskripsi varietas diduga karena varietas Sintanur mampu beradaptasi pada salinitas $(\mathrm{NaCl})$ tinggi.

Hal ini diduga karena salinitas mempengaruhi jumlah anakan produktif yang terbentuk. Namun kondisi demikian tidak memberikan pengaruh besar terhadap varietas yang toleran. Kesmayanti and Mareza (2015) menjelaskan bahwa varietas Sintanur walaupun secara morfologi lebih pendek namun memiliki jumlah anakan dan anakan produktif, luas daun dan luas daun bendera yang lebih besar dibandingkan varietas Margasari, Mekongga dan Batanghari di lahan pasang surut. 
Tabel 8. Rerata Panjang Daun Bendera $(\mathrm{cm})$

\begin{tabular}{ll}
\hline Varietas & Panjang Daun Bendera (cm) \\
\hline Inpari 42 (V1) & $20,83 \mathrm{ab}$ \\
IPB 3S (V2) & $28,25 \mathrm{c}$ \\
IR64 (V3) & $19,11 \mathrm{ab}$ \\
Ciherang (V4) & $16,53 \mathrm{a}$ \\
Mekongga (V5) & $16,83 \mathrm{a}$ \\
IR66 (V6) & $18,42 \mathrm{ab}$ \\
Sintanur (V7) & $22,08 \mathrm{~b}$ \\
\hline
\end{tabular}

Keterangan:

Angka yang diikuti oleh huruf yang sama menunjukkan berbeda tidak nyata menurut uji lanjut BNJ 5\%

Tabel 8. menunjukkan bahwa panjang daun bendera Varietas IPB $3 \mathrm{~S}$
(V2) tertinggi yaitu $28,25 \mathrm{~cm}$, dan terendah pada Varietas Ciherang (V4) yaitu 16,53 $\mathrm{cm}$. Pendeknya daun bendera pada Varietas Ciherang (V4) diduga karena pengaruh genetik. Menurut Wahyuti et al., (2013), varietas IR64 dan Ciherang memiliki luas daun bendera terendah sehingga menyebabkan kemampuan daun bendera untuk melakukan fungsi sebagai source setelah berbunga lebih rendah. Daun bendera mempengaruhi daya hasil padi karena merupakan bagian organ utama yang mendistribusikan hasil fotosintesis menuju malai.

Tabel 9. Rerata Panjang Malai (cm), Jumlah Gabah per Malai (butir), Jumlah Gabah Bernas per Malai (butir) dan Persentase Gabah Hampa (\%)

\begin{tabular}{|c|c|c|c|c|}
\hline Varietas & $\begin{array}{c}\text { Panjang } \\
\text { Malai }(\mathrm{cm})\end{array}$ & $\begin{array}{c}\text { Jumlah } \\
\text { Gabah per } \\
\text { Malai } \\
\text { (butir) }\end{array}$ & $\begin{array}{c}\text { Jumlah Gabah } \\
\text { Bernas per Malai } \\
\text { (butir) }\end{array}$ & $\begin{array}{c}\text { Persentase Gabah } \\
\text { Hampa (\%) (ns) }\end{array}$ \\
\hline Inpari $42(\mathrm{~V} 1)$ & $19,94 \mathrm{bcd}$ & $172,61 b c$ & $161,44 \mathrm{bc}$ & 4,19 \\
\hline IPB 3S (V2) & $22,11 \mathrm{~d}$ & $190,97 \mathrm{c}$ & $177,67 \mathrm{c}$ & 5,05 \\
\hline IR64 (V3) & $20,25 \mathrm{bcd}$ & $127,26 \mathrm{ab}$ & $120,49 \mathrm{ab}$ & 4,25 \\
\hline Ciherang (V4) & $19,42 \mathrm{bc}$ & $118,78 \mathrm{a}$ & $111,81 \mathrm{a}$ & 4,70 \\
\hline Mekongga (V5) & $18,31 \mathrm{ab}$ & $117,28 \mathrm{a}$ & $111,69 a$ & 3,67 \\
\hline IR66 (V6) & $16,58 \mathrm{a}$ & $125,68 \mathrm{ab}$ & $118,17 \mathrm{ab}$ & 2,67 \\
\hline Sintanur (V7) & $21,14 \mathrm{~cd}$ & $116,00 \mathrm{a}$ & $111,31 \mathrm{a}$ & 3,11 \\
\hline
\end{tabular}

Keterangan:

- ns = berbeda tidak nyata

- Angka yang diikuti oleh huruf yang sama menunjukkan berbeda tidak nyata menurut uji lanjut BNJ 5\%

Berdasarkan Tabel 9. tampak Varietas IPB 3S (V2) memiliki panjang malai terpanjang yaitu $22,11 \mathrm{~cm}$, jumlah gabah per malai dan jumlah gabah bernas per malai terbanyak berturut-turut yaitu 190,97 butir dan 177,67 butir. Hal ini diduga panjang malai dan jumlah gabah per malai dikendalikan oleh faktor genetik. Sannang (2002) menyatakan bahwa sifat panjang malai dan kemampuan pembentukan gabah merupakan sifat spesifik yang dimiliki untuk masingmasing tanaman padi.
Jumlah gabah bernas per malai tertinggi adalah Varietas IPB 3S (V2). Hal ini diduga karena Varietas IPB 3S (V2) merupakan varietas toleran salinitas. Mekanisme ketahanan tanaman toleran terhadap salinitas dapat dibagi dua yaitu: penghindaran (avoidance) dan toleransi. Tanaman padi yang toleran dapat mempertahankan keseimbangan antara tekanan osmosis dalam tajuk dan akar dengan media melalui akumulasi ion-ion dalam akar dan prolin dalam tajuknya (Suwarno, 1985). 
Perlakuan varietas tidak memberikan pengaruh yang nyata (ns) terhadap persentase gabah hampa diduga karena curah hujan tinggi saat memasuki fase generatif dan serangan hama walang sangit. Astuti (2012) menyatakan bahwa proses penyerbukan dapat terganggu oleh intensitas curah hujan yang tinggi, sehingga mampu mengurangi hasil tanaman. Hal ini karena proses penyerbukan yang gagal akan menghasilkan gabah hampa sehingga persentase gabah hampa semakin meningkat.

Serangan walang sangit saat masak susu juga menyebabkan tingginya gabah hampa. Menurut Aak (1990), hama walang sangit menyerang tanaman padi yang sudah masak susu, serangan walang sangit muda ataupun dewasa, keduanya menyerang bulir tanaman padi ketika masak susu dengan cara menghisap cairannya sehingga bulir menjadi hampa.

Berdasarkan Tabel 10. tampak Varietas Varietas IPB 3S (V2) menunjukkan bobot 1000 butir yang tinggi yaitu 25,21 gram dibandingkan dengan varietas lain tetapi masih dibawah deskripsi varietas, sedangkan Varietas IR64 (V3) memiliki bobot 1000 butir yang sesuai dengan deskripsi varietas.

Berkurangnya bobot 1000 butir diduga disebabkan oleh tanaman mengalami adaptasi pada cekaman salinitas $(\mathrm{NaCl})$. Menurut Mindari (2009), pengaruh $\mathrm{NaCl}$ terhadap tanaman padi adalah berkurangnya bobot 1000 gabah dan kadar protein total dalam biji karena absorbsi $\mathrm{Na}$ yang berlebihan. Garamgaram atau $\mathrm{Na}+$ yang dapat dipertukarkan akan berdampak pada sifat-sifat tanah apabila dalam keadaan berlebihan dalam tanah. Terhambatnya penyerapan air dan unsur hara melalui osmosis diakibatkan oleh meningkatnya konsentrasi garam terlarut dalam tanah. Hal ini dapat menambah tekanan osmotik. Menurut Mindari (2009) jumlah air yang diserap akar akan berkurang sehingga mengakibatkan jumlah air dalam tanaman menipis. Pada kondisi penyerapan air dan unsur hara yang berkurang menyebabkan tanaman padi tidak mampu menyampaikan fotosintat ke bulir padi secara optimal sehingga menyebabkan bobotnya berkurang.

Tabel 10. Rerata Bobot 1000 Butir (g)

\begin{tabular}{lll}
\hline & \multicolumn{2}{c}{ Bobot 1000 Butir (g) } \\
\cline { 2 - 3 } Varietas & $\begin{array}{l}\text { Kondisi } \\
\text { Cekaman } \\
\text { Salinitas (NaCl) }\end{array}$ & $\begin{array}{l}\text { Deskripsi } \\
\text { Varietas }\end{array}$ \\
\hline Inpari 42 (V1) & $19,80 \mathrm{a}$ & $\pm 24,41$ \\
IPB 3S (V2) & $25,21 \mathrm{c}$ & 28,2 \\
IR64 (V3) & $24,19 \mathrm{bc}$ & 24,1 \\
Ciherang (V4) & $23,84 \mathrm{bc}$ & 28 \\
Mekongga (V5) & $22,64 \mathrm{~b}$ & 28 \\
IR66 (V6) & $19,33 \mathrm{a}$ & 25 \\
Sintanur (V7) & $25,09 \mathrm{c}$ & 27 \\
\hline Keterangan: & & \\
Angka yang diikuti oleh huruf yang sama & yan \\
menunjukkan berbeda tidak nyata & menurut uji \\
lanjut BNJ 5\% & &
\end{tabular}

Berdasarkan Tabel 11. bahwa Varietas Sintanur (V7) menunjukkan produksi dan potensi hasil per hektar tertinggi yaitu 10,61 ton/ha dan 11,05 ton/ha dibandingkan dengan varietas lain sedangkan Varietas IR 66 (V6) menunjukkan produksi terendah 4,79 dan potensi hasil per hektar 5,10 ton/ha namun masih lebih tinggi dibandingkan dengan deskripsi varietas. Produksi dan potensi hasil per hektar Varietas Sintanur (V7) juga melebihi deskripsi varietasnya sebanyak 4,61 ton/ha dan 4,05 ton/ha sedangkan Varietas IPB 3S (V2) lebih rendah dibandingkan dengan deskripsi varietas.

Produksi per hektar ditentukan oleh banyaknya gabah bernas, anakan produktif, bobot 1000 butir dan populasi tanaman per hektar. Varietas IPB 3S (V2) memiliki anakan produktif sedikit sedangkan Varietas Sintanur (V7), anakan produktifnya lebih banyak sehingga produksi dan potensi hasil per hektar juga tinggi. 
Selain itu, produksi dan potensi hasil per hektar yang tinggi pada lahan cekaman salinitas tinggi dengan kadar $\mathrm{NaCl} 5303,45$ ppm diduga tanaman padi toleran mampu beradaptasi. Adaptasi yang dilakukan pada kondisi in vivo adalah menjaga enzim terhadap penonaktivan oleh garam dengan memompakan garam keluar dari sitoplasma. Garam yang disimpan di dalam vakuola, lalu diakumulasikan ke dalam organel-organel atau diekskresi ke luar tanaman kemudian mendesak ion-ion beracun dalam visicle sehingga tanaman menjadi toleran pada konsentrasi garam berlebihan karena terjadi penyesuaian tekanan osmotik tanpa menghambat metabolisme sel (Mindari, 2009).

Tabel 11. Rerata Produksi per Hektar (ton) dan Potensi Hasil per Hektar (ton)

\begin{tabular}{lllll}
\hline \multirow{2}{*}{ Varietas } & \multicolumn{2}{l}{ Produksi per Hektar (ton) } & \multicolumn{2}{l}{ Potensi Hasil per Hektar (ton) } \\
\cline { 2 - 5 } & $\begin{array}{l}\text { Kondisi Cekaman } \\
\text { Salinitas (NaCl) }\end{array}$ & $\begin{array}{l}\text { Deskripsi } \\
\text { Varietas }\end{array}$ & $\begin{array}{l}\text { Kondisi Cekaman } \\
\text { Salinitas (NaCl) }\end{array}$ & $\begin{array}{l}\text { Deskripsi } \\
\text { Varietas }\end{array}$ \\
\hline Inpari 42 (V1) & $10,09 \mathrm{c}$ & 7,11 & $10,77 \mathrm{c}$ & 10,58 \\
IPB 3S (V2) & $5,44 \mathrm{a}$ & 7,04 & $5,85 \mathrm{a}$ & 10,23 \\
IR64 (V3) & $10,33 \mathrm{c}$ & 5,0 & $10,90 \mathrm{c}$ & 6,0 \\
Ciherang (V4) & $8,80 \mathrm{bc}$ & 6,0 & $9,35 \mathrm{bc}$ & 8,5 \\
Mekongga (V5) & $6,73 \mathrm{ab}$ & 6,0 & $7,08 \mathrm{ab}$ & 8,4 \\
IR66 (V6) & $4,79 \mathrm{a}$ & 4,5 & $5,10 \mathrm{a}$ & 5,5 \\
Sintanur (V7) & $10,61 \mathrm{c}$ & 6,0 & $11,05 \mathrm{c}$ & 7,0 \\
\hline Keterangan: Angka yang diikuti oleh huruf yang sama menunjukkan berbeda tidak nyata menurut uji lanjut \\
\multicolumn{3}{c}{ BNJ 5\% }
\end{tabular}

\section{Uji Mutu Benih}

Menurut Sadjad (1993), daya kecambah benih (DB) merupakan tolak ukur untuk mengetahui viabilitas potensial benih (VP). Viabilitas potensial yaitu jika lot benih mampu tumbuh normal pada kondisi yang optimum. Kecepatan tumbuh (KcT) adalah pendugaan vigor karena benih yang lebih cepat tumbuh dapat beradaptasi pada lingkungan yang sub optimum. Keserempakan tumbuh benih (KsT) merupakan tolak ukur dalam mengetahui vigor benih. KsT yang tinggi mengindikasikan vigor kekuatan tumbuh (VKT) absolut yang tinggi karena suatu lot benih yang menunjukan pertumbuhan serempak dan kuat akan memiliki kekuatan tumbuh yang tinggi

Tabel 12. Rerata Daya Berkecambah (\%), Kecepatan Tumbuh (\%) dan Keserempakan Tumbuh (\%)

\begin{tabular}{llll}
\hline Varietas & $\begin{array}{l}\text { Daya Berkecambah } \\
(\%)\end{array}$ & $\begin{array}{l}\text { Kecepatan } \\
(\%)\end{array}$ & $\begin{array}{l}\text { Tumbuh } \\
\text { Tumbuh (\%) }\end{array}$ \\
\hline Inpari 42 (V1) & $94,66 \mathrm{~b}$ & $16,19 \mathrm{~b}$ & $90,00 \mathrm{~b}$ \\
IPB 3S (V2) & $72,25 \mathrm{a}$ & $11,86 \mathrm{a}$ & $65,50 \mathrm{a}$ \\
IR64 (V3) & $92,50 \mathrm{~b}$ & $15,29 \mathrm{~b}$ & $90,00 \mathrm{~b}$ \\
Ciherang (V4) & $94,75 \mathrm{~b}$ & $15,96 \mathrm{~b}$ & $93,00 \mathrm{~b}$ \\
Mekongga (V5) & $93,75 \mathrm{~b}$ & $16,02 \mathrm{~b}$ & $90,25 \mathrm{~b}$ \\
IR66 (V6) & $91,75 \mathrm{~b}$ & $15,44 \mathrm{~b}$ & $88,75 \mathrm{~b}$ \\
Sintanur (V7) & $96,50 \mathrm{~b}$ & $16,46 \mathrm{~b}$ & $95,00 \mathrm{~b}$ \\
\hline
\end{tabular}

Keterangan: Angka yang diikuti huruf yang berbeda dalam satu kolom menunjukkan berbeda nyata menurut uji BNJ taraf error $5 \%$ 
Perlakuan Varietas Sintanur (V7) menunjukkan daya berkecambah, kecepatan tumbuh dan keserempakan tumbuh benih tertinggi yaitu $96,50 \%$, $16,46 \%$, dan 95\%. Varietas Sintanur (V7) berbeda nyata dengan IPB 3S (V2). Varietas IPB 3S (V2) memiliki daya berkecambah, kecepatan tumbuh dan keserempakan tumbuh benih terendah yaitu $72,25 \%, 11,86 \%$ dan $65,50 \%$.

Rendahnya mutu pada padi Varietas IPB 3S (V2) diduga karena dormansi benih. Dormansi benih dapat dipatahkan dengan after ripening. Pada saat penelitian, penyimpanan benih padi dilakukan selama 2 minggu sebelum dilakukan uji mutu benih. Penyimpanan benih selama 2 minggu untuk Varietas IPB 3S (V2) diduga masih belum mampu mematahkan dormansi.

Pada saat budidaya dilapang media tanah yang digunakan mengandung cekaman salinitas $(\mathrm{NaCl})$. Menurut Sugiharto (2016) bahwa kondisi selama budidaya memberikan pengaruh terhadap pembentukan biji. Ichsan (2006) menyatakan bahwa kegiatan metabolisme selama masa pematangan biji menentukan komposisi akhir yang terkandung dalam benih, komposisi dalam benih akan mempengaruhi katabolisme dan anabolisme pada saat benih akan berkecambah. Cekaman salinitas mempengaruhi cadangan makanan dan protein yang berfungsi dalam melakukan proses perkecambahan. Cadangan makanan dari biji diperoleh dari asimilat yang didapat dari proses fotosintesis saat budidaya di lapang. Menurut Kesmayanti and Mareza (2015), fotosintesis sebagai salah satu kegiatan metabolisme primer dalam tanaman yang berperan dalam sintesis dan metabolisme senyawasenyawa organik dalam tanaman seperti gula fosfat, asam nukleat, nukleotida, koenzim dan fosfolipida.

\section{KESIMPULAN}

Berdasarkan hasil penelitian diatas dapat disimpulkan bahwa:

a. Perlakuan varietas memberikan hasil bahwa karakter kualitatif morfologi sesuai dengan deskripsi varietas yang ditanam sedangkan karakter kuantitatif menunjukkan bahwa perlakuan varietas memberikan hasil berbeda nyata pada parameter tinggi tanaman vegetatif serta memberikan hasil berbeda sangat nyata pada parameter tingkat toleransi tanaman, jumlah anakan, jumlah gabah bernas, jumlah anakan produktif, tinggi tanaman generatif, panjang malai, panjang daun bendera, jumlah gabah per malai, bobot 1000 butir, produksi per hektar, potensi hasil per hektar, kecepatan tumbuh, daya berkecambah, dan keserempakan tumbuh benih. Varietas Sintanur memberikan hasil terbaik pada produksi per hektar 10,61 ton/ha, potensi hasil per hektar 11,05 ton/ha, daya berkecambah $96,50 \%$, kecepatan tumbuh 16,46\%/etmal dan keserempakan tumbuh benih 95\%.

b. Tingkat toleransi tanaman menunjukkan bahwa 6 varietas yaitu Inpari 42, IPB 3S, IR64, Ciherang, Mekongga dan Sintanur tergolong toleran, sedangkan IR66 agak toleran pada kondisi tanah tercekam salinitas ( $\mathrm{NaCl}) 5.303,45$ ppm dengan $\mathrm{pH}$ 7,9.

\section{DAFTAR PUSTAKA}

Aak. (1990). Budidaya Tanaman Padi. Jakarta: Kanisius.

Alwi, M. (2014). Prospek Lahan Rawa Pasang Surut untuk Tanaman Padi. (M. Yasin, A. Noor, R. Galib, Suryana, E. S. Rohaeni, \& A. Hasbianto, Eds.), Prosiding Seminar Nasional "Inovasi Teknologi Pertanian Spesifik Lokasi" Banjarbaru. BPTP Kalimantan Selatan, Banjarbaru. 
Astuti, D. N. (2012). Pengaruh Sistem 锂 Pengairan terhadap Pertumbuhan dan Produktivitas Beberapa Varietas Padi Sawah (Oryza sativa L.). IPB (Bogor Agricultural University).

Badan Meteorologi, K. dan G. (2017). 副 Suhu dan Iklim Daerah Jember.

Badan Pusat Statistik. (2016). Luas Panen, Produksi dan Produktivitas Padi Tahun 2013 - 2015.

Balai Besar Penelitian Tanaman Padi. 亥 (2016). Perlu Tersedia Banyak Varietas yang Memiliki Sifat Toleran terhadap Lahan Salin.

Gregorio, G. B., Senadhira, D., \& Mendoza, R. D. (1997). Screening Rice For Salinity Tolerance. Manila, Philippines.

Hayuningtyas, R. D. (2010). Metode Uji Toleransi Padi (Oryza sativa L.) terhadap Salinitas pada Stadia Perkecambahan. IPB (Bogor Agricultural University).

Hutajulu, H. F., Rosmayati, \& Ilyas, S. (2013). Pengujian Respons Pertumbuhan Beberapa Varietas Padi Sawah (Oryza sativa L.) Akibat Cekaman Salinitas. Jurnal Agroekoteknologi Universitas Sumatera Utara, 1(4), 1101-1109.

Ichsan, C. N. (2006). Uji Viabilitas Dan Q Vigor Benih Beberapa Varietas Padi (Oryza sativa L.) Yang Diproduksi Pada Temperatur Yang Berbeda Selama Kemasakan. Jurnal Floratek, 2(1), 37-42.

Kesmayanti, N., \& Mareza, E. (2015).

Studi Komparasi Fase Vegetatif Tanaman Utama Varietas Padi Berpotensi Ratun Tinggi di Lahan
Pasang Surut. Jurnal Lahan Suboptimal, 4(2), 164-170.

Kurniasih, Tarnoyo, \& Toekidjo. (2008).

Eeragaan Beberapa Varietas Padi (Oryza sativa L.) pada Kondisi Cekaman Kekeringan dan Salinitas. Ilmu Pertanian, 15(1), 49-58.

Makarim, A. K., \& Suhartatik, E. (2009). 暿 Morfologi dan Fisiologi Tanaman Padi. Subang: Balai Besar Penelitian Tanaman Padi.

Mindari, W. (2009). Cekaman Garam dan E Dampaknya pada Kesuburan Tanah dan Pertumbuhan Tanaman. Surabaya: UPN "Veteran" Jawa Timur.

Nusifera, S., Lestari, A. P., \& Alia, Y. 暿 (2014). Penampilan dan Parameter Genetik Beberapa Karakter Morfologi Agronomi Dari 26 Aksesi Padi (Oryza spp L.) Lokal Jambi. Jurnal Penelitian Universitas Jambi: Seri Sains, 16(2).

Rusd, A. M. I., Qadir, A., \& Suwarno. E (2011). Pengujian Toleransi Padi (Oryza sativa L.) terhadap Salinitas Pada Fase Perkecambahan. Institut Pertanian Bogor.

Sadjad, S. (1993). Dari Benih Kepada 镐 Benih. Jakarta: Grasindo.

Sannang, N. (2002). Studi Potensi Basil

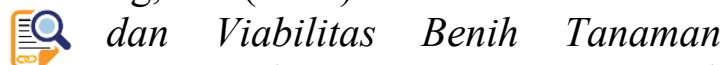
Utama dan Ratoon Dari Tujuh Genotipe Padi Gogo Asal Kalimantan Timur. Bogor Agricultural University (IPB).

Sugiharto, A. (2016). Produksi dan Mutu Benih Padi (Oryza Sativa L.) Ratun Dengan Aplikasi Bakteri Synechococcus sp. pada Berbagai 
Salinitas Media. Politeknik Negeri Jember.

Suwarno. (1985). Pewarisan dan Fisiologi

尌 Sifat Toleran terhadap Salinitas pada Tanaman Padi. Institut Pertanian Bogor.

Syukur, M., Sudjiprihati, S., \& Yunianti,

悲 R. (2015). Teknik Pemuliaan Tanaman (Revisi). Jakarta: Penebar Swadaya.

Utama, M. Z. H., Haryoko, W., Munir, R.,

钢 \& Sunadi. (2009). Penapisan Varietas Padi Toleran Salinitas pada Lahan Rawa di Kabupaten Pesisir Selatan. Jurnal Agronomi Indonesia (Indonesian Journal of Agronomy), $37(2)$.

Wahyuti, T. B., Purwoko, B. S., Junaedi, 暿 A., \& Abdullah, B. (2013). Hubungan Karakter Daun dengan Hasil Padi Varietas Unggul. Jurnal Agronomi Indonesia (Indonesian Journal of Agronomy), 41(3). 